\section{International Scientific Journal Theoretical \& Applied Science}

p-ISSN: 2308-4944 (print) ｅ-ISSN: 2409-0085 (online)

Year: 2015 Issue: 07 Volume: 27

Published: $30.07 .2015 \quad \underline{\text { http://T-Science.org }}$

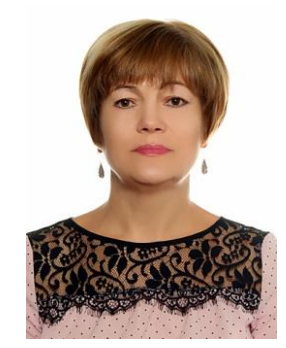

Lyudmila Nikolaevna Iakovenko senior lecturer,

FSEI HPI Kursk State Academy of Agriculture named after prof. I.I. Ivanov, Russia yakovenko66@ya.ru

SECTION 30. Philosophy.

\title{
PURPOSES AND VALUES OF EDUCATION OF V.V. ROZANOV AND PHILOSOPHY OF AGRARIAN POLICY
}

Abstract: The article is devoted to the philosophical analysis of value bases of Russian education in the context of the challenges facing agriculture. It is shown that the ideas of Russian philosophical thought are the basis of the national educational paradigm in terms of reforming. The value system determines the success of today's higher education reform and agricultural industry. The need is stressed to use the original ideas of Russian philosophers in educational practice. The article is of interest to researchers in the field of educational philosophy and axiology.

Key words: educational philosophy, axiology, Russian philosophy, values education, agricultural policy.

Language: Russian

Citation: Iakovenko LN (2015) PURPOSES AND VALUES OF EDUCATION OF V.V. ROZANOV AND PHILOSOPHY OF AGRARIAN POLICY. ISJ Theoretical \& Applied Science 07 (27): 30-33.

Soi: http://s-o-i.org/1.1/TAS-07-27-5 Doi: crossef http://dx.doi.org/10.15863/TAS.2015.07.27.5

\section{ЦЕЛИ И ЦЕННОСТИ ОБРАЗОВАНИЯ В.В. РОЗАНОВА И ФИЛОСОФИЯ АГРАРНОЙ ПОЛИТИКИ}

Аннотация: Статья посвящена философскому анализу иченностных основ российского образования в контексте задач, стоящих перед сельским хозяйством. Показано, что идеи русской философской мысли являются основой отечественной образовательной парадигмы в условиях реформирования. Система ценностей определяет сегоднямний успех реформы высшего образования и сельскохозяйственной отрасли. Подчеркивается необходимость использования оригинальных идей русских философов в образовательной практике. Статья представляет интерес для исследователей в области философии образования и аксиологии.

Ключевые слова: философия образования, аксиология, русская философия, иенности образования, аграрная политика.

\section{Введение.}

Затрагивая самым непосредственным образом сферу агропромышленного комплекса, реформа высшего профессионального образования сталкивается с проблемой ценностного содержания проводимых изменений. Недостаточная позитивная динамика развития российского сельского хозяйства побуждает к активизации извечного философского вопроса «что делать?», не ставшего менее актуальным со времен Н.Г. Чернышевского. Цель нашего исследования состоит в анализе наиболее значимых идей представителей русской философии в лице одного из самых оригинальных ученых и публицистов В.В. Розанова относительно целей и ценностей образования, которые могли составить основу аксиологии образования в условиях разрушения прежних ценностей и становления новой культуры аграрного труда. Люди, занимающиеся сельским трудом, являются носителями особых ценностей: любовь к земле, малой родине, ответственность перед земляками, верность традициям и культурному наследию страны. Актуальность темы исследования определяется значимостью формирования аксилогической парадигмы образования в период интенсивного реформирования всех ступеней образовательной системы, включая профессиональную подготовку бакалавров и магистров для сельского хозяйства. Научная новизна исследования определяется 
недостаточной разработанностью ценностной проблематики в области философии образования, которая сама как область научного исследования является еще новой. В процессе изучения проблемы нами были применены методы теоретического анализа.

Результаты исследования.

Государственная программа развития сельского хозяйства на 2013-2020гг., утвержденная Постановлением Правительства РФ 3717 от 14 июля 2012 года предполагает, что профессионалы высшей квалификации, подготовленные аграрными вузами страны, будут в полной мере соответствовать высоким требованиям времени в условиях конкуренции с европейскими товаропроизводителями. Согласно Доктрине продовольственной безопасности РФ субъекты АПК должны производить не менее $80 \%$ продуктов питания на российской территории. Актуальное импортозамещение товаров, вопросы органического сельскохозяйственного производства, инновационные направления сельскохозяйственной деятельности, проблемы защиты товаропроизводителей и внутреннего регионального продовольственного рынка от экспансии зарубежных аграрных предпринимателей и импорта сельскохозяйственного сырья и продовольствия составляют частные вопросы новой философии аграрной политики. Сегодня обозначены как основные проблемы, так и пути их решения, которые тесно связаны с аграрной политикой государства: модернизация сельских хозяйств и повышение за счет этого их доходности, устойчивое развитие сельских территорий, привлечение молодых специалистов в сферу аграрного производства. Особое место в социально - экономическом преобразовании сельскохозяйственного производства занимает деятельность крестьянских (фермерских) хозяйств страны. Сегодня можно наблюдать положительную динамику производства некоторых видов сельскохозяйственной продукции фермерскими хозяйствами. В этих условиях особенно важно определить цель и назначение гуманитарного образования, без которого невозможно сформировать гармоничную личность профессионала, даже самой высокой квалификации[5].

Исследователи А.А. Фанненштиль, В.В. Щербинин указывают на специфические особенности АПК: низкая концентрация производства в сельской местности, недостаток рабочих мест, отсутствие разнообразия специальностей и, как следствие, монополизм работодателей. При этом исследователями отмечается невысокий уровень мобильности сельских жителей, а также то, что особенности менталитета селян проявляются в осторожности и консерватизме. Следовательно, только долговременная работа с выпускниками школ из сельских районов, помощь в профессиональном самоопределении поможет сделать осознанный выбор профессии аграрного профиля[6]. Цели и ценности в системе мировоззрения будущих студентов определяют то направление послевузовской деятельности, которое выбирают будущие специалисты высшей квалификации. Это представляется особенно важным в ситуации, когда выпускники устраиваются на работу не по специальности, обозначенной в дипломе. Их принуждают к этому различного рода социально - экономические причины: отсутствие отдельного жилья, невысокий уровень зарплаты, неразвитость в сельской местности современной сферы развлечений. Поэтому молодой специалист с высшим образованием, для которого значительной ценностью выступает сельская местность «малая родина», где он родился и вырос, где живут его близкие и друзья, все же выбирает благоустроенную городскую жизнь с работой не по специальности[7; 8]. Прагматизм Д. Дьюи, составляющий основу западного образования, трактует цели и ценности образования с точки зрения пользы. Проблема определения четких ориентиров направленности молодежи на приобретение сельскохозяйственного образования, повышение привлекательности сельскохозяйственных профессий является актуальной также для европейских вузов и колледжей $[9 ; 10]$.

Одним из традиционных подходов в гуманитарных науках выступает обращение к личности субъекта, системе ее ценностных предпочтений. Философия, сохраняя теоретическую основу и являясь методологическим основанием современного образования, приобретает прикладной аспект, приближаясь к нуждам общества. Хотя аксиологическая составляющая никогда не покидала сферу философии, с наступлением ХХІв. об аксиологии и философии образования стали говорить с большим воодушевлением, чему свидетельство многочисленные монографии и диссертационные исследования последних десятилетий. Начала философии образования в России, которой сегодня отводится одна из ключевых ролей в деле интенсификации социально - экономического развития страны, были положены в конце ХІХв. философско публицистическими трудами педагогов К. Д. Ушинского («Человек как предмет воспитания. Опыт педагогической антропологии», 18681869) с идеями народности воспитания и 
образования и П.Ф. Каптерева («Новая русская педагогия, ее главнейшие направления и деятели», 1897) с индивидуализацией воспитания и обучения. В частности, П.Ф. Каптереву в 1915г. министром народного просвещения П.Н. Игнатьевым было поручено подготовить реформу российского образования. Религиозный философ В.В. Розанов и философнеокантианец С.И. Гессен могут быть по праву отнесены к основателям российской философии образования, благодаря своим выдающимся работам, где мы находим осмысление духовных национальных ценностей, отражение вопросов обучения и воспитания с аксиологической точки зрения. Следует отметить, что хотя В.В. Розанов не создал стройную систему ценностей образования, однако в работах, касающихся вопросов гимназического или университетского обучения, выразил как глубокое понимание проблем российской образовательной системы и менталитета граждан, так и обозначил области применения философии образования. Изданная в 1923г. работа С.И. Гессена «Основы педагогики. Введение в прикладную философию» отражает многие положения целей и ценностей образования, высказанные ранее как В.В. Розановым, так и другими учеными того времени. В первую очередь это касается нравственного воспитания и понимания сущности личности[2]. Позднее С.И Гессен, рассматривая сущность послереволюционных изменений подхода к воспитанию человека, отмечает в статье «Судьба коммунистического идеала образования» (1933) непреложимость предлагаемого идеала воспитания к реальной жизни, его текучесть, многоликость и неустойчивость[1].

Спустя столетие после первой публикации труды В.В. Розанова стали доступны для широкого круга исследователей. О.В. Долженко (1995), В.М. Розин (1996), А.Н. Николюкин (2001), В.А.Фатеев, Д.А.Кравцов (2002), Р.А Барзукаева (2004), И.В.Горина (2009), Е.В. Свирская (2012) в монографиях и диссертационных исследованиях, посвященных философскому наследию В.В. Розанова, показали традиционность связи философии и образования как источника интеллектуального и духовного прогресса. Обратимся к анализу работы В.В. Розанова «Сумерки просвещения» (1893), изданной в 1899г. В предисловии В.В. Розанов отмечает, что темой его внимания является не столько русская школа, сколько почва, на которой стоит эта школа, «...не имеющая за себя других аргументов, кроме подражательности и традиции». «Забыта именно философія воспитанія; не приняты во вниманіе такъ сказать геологическіе пласты, коихъ поверхностную пленку «назема» мы поэтому такъ безуспьшно пашемъ»[3, с.1]. Заметим, что философ не отрицает, что существует дидактика и педагогика как ремесло или искусство и эта система работает, обеспечивая определенный уровень образования, но его авторская позиция состоит в акцентировании философии воспитания и образования, как базиса, отсутствие которого приводит к неэффективности всей системы образования в целом. С.С. Розанов всегда стремился сделать свою жизнь осмысленной и направленной на благие цели. Будучи студентом третьего курса университета будущий самобытный ученый написал одну из своих первых работ «Цель человеческой жизни» (1892), где отмечает, что в рамках сознательного существования человека вопрос о цели является одним из самых первостепенных. В традициях русской философии С.С.Розанов подчеркивает, что идея цели представляет собой внутренний и субъективный акт, который посредством деятельности воплощается в действительности. Качество цели это нечто совершенное и не подлежащее изменению, где идеальная полнота является логической необходимостью для всякой цели[4].

Беспокоясь не без основания о судьбе российского просвещения, В.В. Розанов ставит вопросы о том, чему и как учить и какими должны быть те, кто берет на себя ответственную миссию обучения и образования человека. Отвечая насущным требованиям сегодняшней подготовки профессионала высшей квалификации для аграрного сектора экономики это должен быть человек с устойчивой патриотической направленностью, четкой гражданской позицией, пришедший, скорее всего, от земли и с детства впитавший в себя любовь к родному краю.

\section{References:}

1. Gessen SI (1993) Sud'ba kommunisticheskogo ideala obrazovanija [The fate of the communist ideal education]. Pedagogika [Pedagogy], no. 6 (1993): 59-64.
2. Gessen SI (1995) Osnovy pedagogiki. Vvedenie v prikladnuju filosofiju [Basics of Pedagogy. Introduction to applied Philosophy]. Moscow: Shkola-Press Publ., 1995. 448p. 
3. Rozanov VV (1899) Sumerki prosveshhenija. Sbornik statej po voprosam obrazovanija [Twilight of the Enlightenment. A collection of articles on education]. St. Petersburg: M. Merkusheva Publ., 1899. 240p.

4. Rozanov VV (2001) Cel' chelovecheskoj zhizni [The purpose of human life ]. Moscow: Graal Publ., 2001. 68p.

5. Spektor DM (2015) Smysl i naznachenie gumanitarnogo obrazovanija (v poiskah «tochki sborki») [The meaning and purpose of liberal education (in search of the "assemblage point"]. Alma mater. Vestnik vysshej shkoly [Alma mater. Journal of higher school], no.2 (2015): 89-94.

6. Fannenshtil' AA, Shherbinin VV (2004) Podgotovka diplomirovannyh specialistov APK $\mathrm{s}$ vysshim obrazovaniem $\mathrm{v}$ razreze sel'skih rajonov Altajskogo kraja [Train certified agricultural specialists with higher education in the context of rural areas of the Altai territory].Vestnik Altajskogo gosudarstvennogo agrarnogo universiteta [Bulletin of the Altai State Agrarian University], no.4 (2004):189193.
7. Jakovenko LN (2015) Aksiologicheskie osnovanija patriotizma $\mathrm{v}$ kontekste filosofii obrazovanija i agrarnogo truda [Axiological foundations of patriotism in the context of the philosophy of education and agricultural labour]. Vestnik Brjanskoj gosudarstvennoj sel'skohozjajstvennoj akademii [Bulletin of the Bryansk State Agricultural Academy ], no.3(2015): 47-51.

8. Jakovenko LN (2015) Vnutrennjaja i vneshnjaja motivacija vybora professii sub'ektami obrazovatel'nogo processa [Internal and external motivation to choose a profession of educational process]. Sborniki konferencij NIC «Sociosfera» [Conference proceedings the SPC "Sociosphere"], no.5( 2015): 65-70.

9. Howlett Charles F (2008) John Dewey and Peace Education. Encyclopedia of Peace Education, Teachers College, Columbia University. 2008, pp.1-5.

10. Gowans K (2013) Effects of Animal Science Agricultural Education Course Completion on Urban High School. Students' Career Choice. All Graduate Theses and Dissertations. Paper 2063. 2013. 83p. 